fifty years, especially from sites in the Red Deer Valley. These specimens, mostly late Cretaceous, make up some fine exhibits in important museums such as the American Museum of Natural History in New York. However, most of the collectors who have worked in the Province have come from museums or universities in the East; the University of Alberta has not played a significant part in the development of vertebrate palæontology in the Province.

The International Congress of Zoology in Washington provided an opportunity to bring to Alberta a group of vertebrate palæontologists from various countries who could provide advice about the possibilities for developing vertebrate palæontology in this Province. The Departments of Geology and Zoology, with the support of funds from the National Research Council of Canada and the University of Alberta, invited about fifteen visitors to come to Alberta for a programme of scientific meetings and a field-trip to visit sites of palæontological interest. The visitors included Dr. A. S. Romer (Harvard), Dr. Bjorn Kurtén (Finland), Dr. Rosendo Pascual (Argentina), Dr. T. S. Westoll (Neweastle upon Tyne), Dr. W. E. Swinton (Toronto), Dr. W. A. Clemens (Kansas), Dr. Heinz Tobien (Mainz), Dr. Charles Devillers (Paris), Dr. E. H. Colbert (New York), Dr. Loris Russell (Ottawa), Dr. Wann Langston (Texas) and Dr. Charles Stermberg (Ottawa), of whom the last three had collected extensively in the area. A number of other palæontologists attended from various parts of Canada and the United States, and, together with members of the staff of the University and the Research Council of Alberta, a full party of forty persons travelled on the field-trip.

The programme consisted of scientific reports on the following subjects: "The Cretaceous in Alberta", by Dr. Wann Langston, jun.; "The Tertiary in Western Canada", by Dr. Loris S. Russell; "The Pleistocene in Alberta", by Drs. L. A. Bayrock and W. A. Fuller (Edmonton). These papers were delivered in Edmonton and provided an excellent background for discussions and preparation for the field trip. All the speakers at this session expressed the view that great opportunities for vertebrate palæontology exist in Alberta, and that, although the day of spectacular dinosaur collecting was not necessarily at an end, there were other aspects awaiting investigation which might be more rewarding scientifically. Dr. Langston stressed that results might be expected from an intensive search for fossil fishes and remains of early vertebrates in the Palæozoic and Triassic exposures in the Rocky Mountains. He also reviewed the records of Cretaceous dinosaurs and stressed that there were many outstanding problems demanding further investigation.
Dr. Russell described his own experiences in collecting remains of Tertiary mammals in the Cypress Hills of Saskatchewan and underlined the need for the careful and painstaking collection of material found in bone beds that are exposed by quarrying and erosion. Dr. Bayrock described the new knowledge that is emerging about the extent of glaciation in Western Canada and showed how much we could learn about this from an exact knowledge of the mammalian fauna of Pleistocene times, a fauna which has left abundant evidence of its existence in a number of sites close to Edmonton. Dr. Fuller described the knowledge that exists already about different species of bison which lived in Alberta in glacial and inter-glacial times.

During the field-trip, the party visited sites in the Red Deer Valley, including Drumheller, where there is an active local museum society, and Steveville, where the Provincial Government has established a park in which several dinosaur skeletons have been exposed in situ and protected from the weather. Visits were also made to the Cypress Hills in Saskatchewan, where an Oligocene bone bed was examined, and to the Milk River Canyon in South-eastern Alberta, where a magnificent set of dinosaurbearing sandstones of the Upper Cretaceous is exposed.

The field-trip and the conference ended at the Calgary campus of the University of Alberta with an informal discussion of the impressions that the group had gained from the trip about the future of vertebrate palæontology in Alberta. Almost all the views expressed were extremely encouraging and, as a result, the Departments of Geology and Zoology are hoping to appoint a vertebrate palæontologist to the staff of the University in the near future. It is hoped also that field work with a new orientation will begin in the summer of 1964 , concentrating on the Cretaceous mammalian fauna of the Upper Edmonton Formation, and collecting at localities where fossil fishes are known to occur.

Public lectures were given in Edmonton by Drs. Colbert and Russell and in Calgary by Dr. Romer. The Alberta Society of Petroleum Geologists participated in these events. Members of the conference were entertained by the Government of the Province of Alberta, by the Edmonton Zoological Society, by the Calgary Zoological Soeiety and by the Prineipal of the University of Alberta, Calgary. A full report of the proceedings of the conference will be available shortly and will be sent on request to anyone interested. Persons desiring information about the further development of the programme of vertebrate palæontology in Alberta should write to the Head of the Geology or the Zoology Departments, University of Alberta, Edmonton, Canada.

\section{M. Ross}

\title{
PLANT POLYSACCHARIDES
}

\begin{abstract}
A SYMPOSIUM on the chemistry and biochemistry of plant polysaccharides was recently organized by the Plant Phenolies Group. The meeting was held at the School of Pharmacy, University of London, on January 7.

The chairman for the morning session was Prof. J. W. Fairbairn (School of Pharmacy) and the first speaker was Prof. E. J. Bourne (Royal Holloway College), who reviewed the methods available for the determination of polysaccharide structures. The development of new techniques has been very rapid during the past twenty years. Paper chromatography was, without doubt, the most important contribution to polysaccharide chemistry, and in recent times the use of gas-liquid chromatography for the analysis of methylated sugars and trimethylsilyl derivatives has been an important break-through. Even more exciting possibilities may come from the full application of enzymatic and immunochemical techniques.
\end{abstract}

Dr. W. J. Whelan (Lister Institute of Preventive Medicine) discussed the structure of the two starch components, amylose and amylopectin. The main structures are now well known, but some aspects of the fine structures of these polysaccharides are in dispute and present-day interest is centred around these. Of particular interest are the few glucose residues in amylose which possess linkages in addition to $\alpha-1,4$. The most recent evidence suggests that these 'anomalous' linkages are $\alpha-1,6$. The original claim that $\alpha-1,3$-linkages are present in amylopectin may be incorrect. One of the latest enzymes to be used for the examination of these fine structures is pullulanase, which is specific for the cleavage of $\alpha-1,6$ linkages.

Prof. H. K. Porter (Imperial College of Science and Technology) followed Dr. Whelan and described the development of ideas regarding the formation and break- 
down of starch in vivo with particular reference to the role of sucrose in these processes and the observations that have been made on the plant tissues that are involved. It is now generally believed that phosphorylase is not the major enzyme concerned in vivo with the formation of $\alpha-1,4$-linkages in starch but that a uridine diphosphate glucose : $\alpha$-1,4-glucan $\alpha$-4-glucosyltransferase is required. Prof. Porter pointed out, however, that, so far, only a very low incorporation of glucose into starch had been achieved in vitro using this enzyme system and that the identity of the initial acceptor substrate for such a reaction in vivo was not known.

In the afternoon Prof. W. B. Whalley (School of Pharmacy) took the chair, and the first lecture on hemicelluloses, gums and pectic substances of higher plants was given by Dr. G. O. Aspinall (University of Edinburgh). These heteropolysaccharides, which are extremely complex, have been the subject of chemical investigation for many years. In most cases very little is known of the detailed arrangement of the various monosaccharide residues, but the polysaccharides can be grouped according to cortain common structural features. New techniques such as the stabilization of labile glycosidic bonds by oxidation of the glyeone moieties and improved enzymatic degradation procedures have allowed significant progress to be mado in this field during the past few years.

The polysaccharides present in scaweeds exhibit many of the complexities of those present in higher plants and, in addition, some, such as carrageenin and fucoidin, possess sulphate ester groups which complicate the determination of structures. An account of the progress which hus been made with molecules of this type was given by Dr. E. Percival (Royal Holloway College). Other polysaccharides which are present in theso algae include alginic acid and laminarin. The former has for some time successfully resisted detailed analysis. The position of L-glucuronic acid in this polysaccharide has recontly attracted much attention. In the case of laminarin there have been differences of opinion over the state of the mannitol which is present in this polymer.

The final lecture in the symposium was delivered by Dr. L. Hough (University of Bristol), who described the incorporation of carbon-14 into the heteroglycan constituents of plum and holly leaves and tho biosynthetic significance of these labelling experiments. It is apparent that even in mature leaves there is a turnover of some of the structural polysaccharides. The rapid turnover of D-glucitol which occurs in plum leaves wus also mentioned and, in addition, the recent and rather unoxpected discovery by the Bristol group that the leaves of Itia spp. contain $\mathrm{D}$-allulose and allitol.

The attendance at the symposium was more than 100 . and both academic and industrial interests in the chemical and biological fields were represented. The success of the meeting was perhaps due to the fact that eleven years had elapsed since plant polysaccharides were last the subject of a symposium in the United Kingdom. The Plant Phenolics Group will eontinue to foster interest in all aspects of the chemistry and biochemistry of plant constituents and to promote discussion and interchange between scientists of all disciplines who are involved with these compounds.

J. B. Рridham

\title{
RATIOS OF STRONTIUM-90 TO CALCIUM IN MILK AND IN THE BONES OF INFANTS
}

\author{
By DR. J. F. LOUTIT, C.B.E., F.R.S. \\ Medical Research Council Radiobiological Research Unit, Harwell \\ AND
}

DR. R. SCOTT RUSSELL, DR. R. S. BRUCE and B. O. BARTLETT

Agricultural Research Council Radiobiological Laboratory, Letcombe Regis, Wantage

$\mathrm{A}^{\mathrm{s} \text { thon }}$ the radiation dose which man receives from strontium-90 depends on its concentration in bone, the effects of environmental contamination with this nuclide can be assessed most directly by the analysis of bone. The difficulties of obtaining adequately representative samples of bone, particularly from sparsely populated areas, make it necessary to estimate the exposure of the population largely from the results of dietary surveys. Not only is it possible to sample foodstuffs in the United Kingdom on a considerably more representative scale, but also the levels of contamination observed in commodities, such as milk, which are produced throughout the year can provide valuable early information on changes in man's exposure. The conclusions which such measurements justify depend, however, on the reliability with which they can be used to deduco the concentration of strontium-90 in bone.

It is well established that there is a close interrelationship between strontium-90 and calcium in their transfer from diet to bone. For this reason measurements are normally expressed as ratios of strontium-90 to calcium. Because the concentration of calcium in bone is relatively constant, the radiation dose received by both bone and the adjacent tissues can be directly inferred from the ratio in bone. Discrimination against strontium-90 relative to calcium causes the ratio in the bone to be lower than in the diet from which it is derived. The relationship between these two ratios is frequently described as the 'observed ratio' (that is, " $\mathrm{s} \mathrm{Sr} / \mathrm{Ca}$ bone divided by
${ }^{90} \mathrm{Sr} /\left(\mathrm{Ca}_{\text {diet }}\right)$. It has been widely accepted that $0 \cdot 25$ is a generally applicable value for this ratio ${ }^{1,2}$. the most exten. sive information being that assembled by the United Nations Scientific Committee on the Effects of Atomic Radiation. Estimates of the 'observed ratio' from survey data are, however, open to considerable uncertainty. 'The actual composition of diet is seldom known precisely and the extent to which it is contaminated varies markedly over short periods. Thus, the mean ratio of strontium-90 to calcium in the diet from which the bone has been formed is uncertain even for the younger age groups. Further complications arise because the 'observed ratio' may be affected by the composition of the $\operatorname{diet}^{3}$, by the period which has elapsed since the two elements were deposited in bone $e^{4}$ and by the age of the subject ${ }^{5-9}$. Increasing evidence that less discrimination against strontium occurs in infants makes it particularly desirable to review the manner in which the ratio of strontium-90 to calcium in their bones should be predicted from the results of dietary surveys.

In practice, knowlodge of the relationship betweon the ratio of strontium-90 to calcium in milk and that in the bones of infants is of particular importance. Not only is milk a major food of infants, but, under conditions pertaining so far, the bones of infants show the highest ratio of strontium-90 to calcium ${ }^{10}$. A further reason for directing special attention to milk emerges from a consideration of the sources from which infants may receive their food. If fresh milk is the major component of their diet, 